\title{
NARODNA KNJIŽNICA \\ U ODGOVARANJU NA ČITATELJSKE POTREBE I INTERESE MLADIH SREDNJOŠKOLSKE DOBI
}

\author{
PUBLIC LIBRARY IN RESPONDING \\ TO THE READING NEEDS AND INTERESTS \\ OF SECONDARY SCHOOL YOUNG PEOPLE
}

Marijana Mikić
mag. informatologije, Đakovo
mikicmarijana612@gmail.com

Ivana Martinović

Filozofski fakultet

Sveučilište u Osijeku

imartinovic@knjiga.ffos.hr

UDK / UDC: 027.022:028-057.87(497.54 Đakovo) Izvorni znanstveni rad / Original scientific paper Primljeno / Received: 8. 7. 2021.

Prihvaćeno / Accepted: 20. 10. 2021.

\section{Sažetak}

Cilj. Cilj je ovog rada utvrditi kakve su čitateljske potrebe i interesi učenika Gimnazije A. G. Matoša u Đakovu, ispunjava li ih Gradska knjižnica i čitaonica Đakovo (u daljnjem tekstu GKČ Đakovo) te potiče li GKČ Đakovo mlade na čitanje iz užitka.

Metodologija. Istraživanje je provedeno tijekom svibnja 2020. godine u Gimnaziji A. G. Matoša u Đakovu, a korištena je metoda online anketiranja. U istraživanju je sudjelovalo 75 učenika od prvog do četvrtog razreda

Rezultati. Rezultati su pokazali da ispitanici čitanje smatraju bijegom od stvarnosti i zabavom, a da im u isto vrijeme čitanje služi i za razvijanje vještina. Iz rezultata je vidljivo da ispitanici najviše vole čitati ljubavni i kriminalistički žanr, kao i knjige koje sadrže likove s kojima se mogu poistovjetiti te koje im pomažu savladati svakodnevne

Vjesnik bibliotekara Hrvatske 64, 2(2021), 59-84

ISSN 0507-1925 
poteškoće. Nadalje istraživanje je pokazalo da većina ispitanika koristi usluge GKČ Đakovo te da su njima zadovoljni, ali da većinom ne nazoče aktivnostima koje knjižnica organizira. Jedan dio ispitanika nisu korisnici GKČ Đakovo jer ne čitaju u slobodno vrijeme ili čitateljske potrebe ispunjavaju na druge načine. Rezultati su također pokazali da većina ispitanika ne zna potiče li ih GKČ Đakovo na čitanje, niti što bi knjižnica mogla poduzeti da ih više potakne na čitanje iz užitka.

Ograničenja. Istraživanje je provedeno online u razdoblju kada se nastava odvijala online u virtualnim učionicama, što je rezultiralo manjim uzorkom od onog koji se očekivao da se istraživanje provodilo uživo u školi uz izravan kontakt s učenicima.

Praktična primjena. Rezultati mogu poslužiti kao smjerokaz za unapređenje postojećih i oblikovanje budućih programa i usluga namijenjenih mladima u GKČ Đakovo.

Vrijednost. Istraživanjem se došlo do spoznaja o čitateljskim potrebama i interesima učenika đakovačke gimnazije te ispunjava li ih GKČ Đakovo. Ovaj rad doprinosi postojećem znanju o čitateljskim potrebama i interesima mladih u Republici Hrvatskoj, kao i o ulozi narodnih knjižnica u ispunjavanju potreba i interesa svojih mladih korisnika.

Ključne riječi: čitateljski interesi, čitateljski potrebe, Gimnazija A. G. Matoša, Gradska knjižnica i čitaonica Đakovo, narodna knjižnica

\section{Abstract}

Purpose. The purpose of this paper is to determine the reading needs and interests of high school students in the Gymnasium A. G. Matoš Đakovo, whether the Đakovo City library meets them and whether the public library encourages young people to read for pleasure.

Methodology. The research was conducted during May 2020 at the Gymnasium A. G. Matoš Đakovo. The research was based on an online survey which was completed by 75 students of the gymnasium.

Results. The results have shown that the respondents think of reading as an escape from reality. Also, they consider that reading is fun and that it helps them develop skills. The results have shown that the respondents prefer to read the romance and crime genres, as well as books featuring characters with whom they can identify and books about everyday difficulties. Furthermore, the research has shown that the majority of the respondents use the services of the public library and that they are satisfied with them, but that most of them do not attend the activities organized by the library. Some of the respondents are not users of the Đakovo City library because they do not read in their free time or fulfill their reading needs elsewhere. However, the results have shown that most respondents do not know whether the public library encourages them to read or what the library could do to encourage them to read more for pleasure. 
Limitations. The research was conducted online at the time when the classes took place online in virtual classrooms, resulting in a smaller sample than what could have been expected if the research had been conducted live in the school with direct contact with students.

Practical use. The results can serve as a guideline for improving the existing and developing the future programs and services for young people in the public library in Đakovo.

Value. The research provides an insight into the reading needs and interests of gymnasium students in the town of Đakovo and whether the public library fulfills them. This paper contributes to the existing knowledge about the reading needs and interests of young people in Croatia, as well as the role of public libraries in meeting the needs and interests of their young patrons.

Keywords: Gymnasium A. G. Matoš Đakovo, public library, Public Library Đakovo, reading interests, reading needs

\section{Uvod}

Čitanje je aktivnost koja je pojedincu potrebna za obavljanje svakodnevnih, čak i onih najjednostavnijih životnih zadataka. Osim što im omogućuje normalno djelovanje i rješavanje problema u životu, čitanjem ljudi dolaze do informacija, uče, ali i uplovljavaju u svijet mašte i zabavljaju se, zbog čega je iznimno važno razvijati naviku čitanja. Budući da je sama aktivnost čitanja vrlo složen proces razmišljanja, prosuđivanja i vrednovanja, ona nam razvija razne vještine i potiče nas na logičko razmišljanje i zaključivanje, donošenje odluka, razvijanje ličnosti, stvaranje stavova i slično. ${ }^{1}$ Upravo u tome veliku ulogu ima i čitanje iz užitka za koje pojedinac sam, prema svojim interesima i željama, odabire što će, kada i kako čitati. Temelj za čitanje iz užitka jest razvijanje čitateljske navike koja započinje razvijanjem vještine čitanja, a nastavlja se kada pojedinac zbog čitanja onoga što mu je zanimljivo razvije potrebu za čitanjem i tu potrebu pretvara u naviku. Dakle, čitateljske navike, potrebe i interesi međusobno su povezani, pa čak i ovisni jedni o drugima. ${ }^{2}$ Iz navedenih razloga jasno je da je poticanje čitanja iznimno važno, u prvom redu kod djece, potom, s posebnim naglaskom, kod mladih jer se oni nalaze u razdoblju adolescencije tijekom kojeg puno njih odustane od samovolj-

Usp. Anish, C.A.; J. Jincy. Reading habits of higher secondary school students: A Study. // Imperial Journal of Interdisciplinary Research 3, 5(2017), str. 1939. [citirano: 2021-06-02]. Dostupno na: http://www.onlinejournal.in/IJIRV3I5/342.pdf.

2 Usp. Maharasi, I.; S. Maulani. High school students' reading habit and perception on reading for pleasure. // International Journal of Indonesian Education and Teaching 3, 1(2019), str. 81-85. [citirano: 2021-06-02]. Dostupno na: https://www.researchgate.net/publication/335012807 HIGH_SCHOOL_STUDENTS'_READING_HABIT_AND_PERCEPTION_ON_READING_FOR_PLEASURE. 
nog čitanja, ${ }^{3}$ a uz to i od odlaska u knjižnicu. ${ }^{4}$ Razlozi tome leže u činjenicama što mladi na raspolaganju imaju manje vremena nego u djetinjstvu, a istovremeno im se, zbog odrastanja, mijenjaju i povećavaju interesi za razne druge aktivnosti. Promjena u interesima i opadanje aktivnosti čitanja iz užitka kod mladih moguće je uočiti i promotre li se rezultati različitih istraživanja slobodnog vremena mladih koja su pokazala da mladi čitaju u manjoj mjeri, a slobodno vrijeme više vole provoditi u druženju s prijateljima, izlascima, korištenju računala, gledanju televizije, slušanju glazbe, hobijima i slično. ${ }^{5}$ Stoga je upravo narodnim knjižnicama jedna od ključnih zadaća, ali i izazova, poticati razvijanje vještine čitanja i čitanja iz užitka, ${ }^{6}$ a mladima trebaju posvetiti posebnu pozornost, prepoznati promjene $u$ njihovim interesima i potrebama te im osigurati okruženje u kojem će se oni osjećati dobrodošlo i gdje će moći pronaći ono što žele čitati. ${ }^{7}$

\section{2. Čitateljske potrebe i interesi}

U stručnoj i znanstvenoj literaturi nema posebno izražene definicije čitateljskih potreba kao zasebnog koncepta. Razlog tome mogao bi se pronaći u uskoj povezanosti s čitateljskim navikama i interesima, s obzirom na to da su vrlo slične čitateljskim interesima, a dio su procesa stvaranja čitateljske navike, pa se na čitateljske potrebe može gledati više kao na dio procesa razvijanja čitateljskih navika i interesa nego kao zaseban koncept. ${ }^{8}$ Uz to, stavlja ih se i u kontekst knjižnica, ističući kako knjižnice trebaju pružati usluge, organizirati programe i izgraditi zbirke koje će ispuniti informacijske, razvojne, obrazovne i ostale potrebe svojih korisnika. ${ }^{9}$ Dakle, iako ne postoji posebno istaknuta definicija čitateljskih potreba,

3 Usp. IFLA Professional Report: Guidelines for library services for young adults, str. 2. [citirano: 2020-06-02]. Dostupno na: https://www.ifla.org/files/assets/libraries-for-children-and-ya/ publications/ya-guidelines2-en.pdf.

4 Usp. Snowball, C. Enticing teenagers into the library. // Library Review 57, 1(2008), str. 26. [citirano: 2021-26-10]. Dostupno na: https:/espace.curtin.edu.au/bitstream/handle/20.500.11937/6057/20507_downloaded_stream_495.pdf?sequence=2\&isAllowed=y.

5 Usp. Ilišin, V.; F. Radin. Interesi i slobodno vrijeme mladih. // Mladi uoči trećeg milenija. / urednici V. Ilišin i F. Radin. Zagreb: Institut za društvena istraživanja u Zagrebu; Državni zavod za zaštitu obitelji, materinstva i mladeži, 2002. Str. 283. [citirano: 2021-10-07]. Dostupno na: http:// knjiznica.idi.hr/epb/Mutm.pdfT; Također usp. i Ilišin, V. Neke dimenzije slobodnog vremena mladih. // Generacija osujećenih: Mladi u Hrvatskoj na početku 21. stoljeća. / urednice V. Ilišin i V. Spajić Vrkaš. Zagreb: Institut za društvena istraživanja u Zagrebu, 2017. Str. 300.

6 Usp. Sabolović-Krajina, D. Čitanje: Sposobnost važnija nego ikada. // Riječi teške od života: Suvremene težnje u nastavi hrvatskoga jezika: Stazama Lovrakovih sljedbenika: Zbornik. / glavni urednik V. Strugar. Bjelovar: Ogranak Hrvatskog pedagoškog-književnog zbora Bjelovarsko-bilogorske županije, 2003. Str. 36.

7 Usp. IFLA Professional Report. Nav. dj., str. 2.

8 Usp. Maharasi, I.; Maulani, S. Nav. dj., str. 85.

9 Usp. Gorman, M.; Suellentrio, T. The philosophy of service to young adults. New York: Neal-Schuman Publishers, 2009. Str. 3-8. 
moguće ih je opisati kao funkcionalne potrebe koje pojedinac s razvijenom navikom čitanja osjeća, a može ih ispuniti samo čitanjem teksta koji je samostalno odabrao i koji odgovara njegovim interesima. ${ }^{10}$

Čitateljski interesi najčešće se izražavaju kroz žanr i/ili predmet o kojem pojedinac voli čitati, a oni se mogu razlikovati ovisno o spolu, godinama i stupnju obrazovanja pojedinca. ${ }^{11}$ Osim toga, na njih utječu i drugi unutarnji i vanjski čimbenici koje je moguće podijeliti u tri kategorije. Prva se odnosi na sadržaj, formu, količinu, kvalitetu i duljinu teksta. Drugoj kategoriji pripadaju dob, spol, inteligencija, psihološke potrebe i sposobnosti čitanja, a treća kategorija obuhvaća dostupnost knjiga, utjecaj okoline te socioekonomski status pojedinca. Stoga, iako se čitateljski interesi najčešće promatraju kroz žanr i teme o kojima pojedinac voli čitati, na njih utječe i mnogo drugih čimbenika, pa tako svoju ulogu u oblikovanju čitateljskih interesa pojedinca ima i to kojim tekstovima pojedinac uopće ima pristup, pridaje li više pozornosti kvaliteti djela ili nečemu drugome, npr. popularnosti autora. Utjecaj imaju i njegovi životni stavovi, razina razvijenosti sposobnosti čitanja i sl. Dakle, čitateljski interesi određuju što će i kako pojedinac čitati, a mogu se istražiti i saznati jedino kroz izravno anketiranje čitatelja. ${ }^{12}$ Takva istraživanja trebale bi prvenstveno provoditi narodne knjižnice jer bi im rezultati uvelike pomogli u osmišljavanju programa i usluga za sve korisničke skupine, a što bi potencijalno rezultiralo većom posjećenošću, porastom broja korisnika te većim zadovoljstvom korisnika uslugama, što svakako treba biti jedan od ciljeva svih narodnih knjižnica. ${ }^{13}$

\section{Narodna knjižnica u službi mladih}

Narodna je knjižnica organizacija koja kroz svoje usluge treba osigurati pristup književnim djelima, znanju i informacijama te podupirati cjeloživotno obrazovanje, a svojim radom treba poticati i sudjelovati u razvijanju čitateljskih vještina i navika svojih trenutnih i potencijalnih korisnika i korisničkih skupina. ${ }^{14}$ Jedna

10 Usp. Kunz, J. C. Understanding your reader's needs and wants can lead to higher book sales, 2019. [citirano: 2020-07-07]. Dostupno na: https://kunzonpublishing.com/2019/03/understanding-your-readers-needs-and-wants-can-lead-to-higher-book-sales.

11 Usp. Kushmeeta Chettri, M.; S. K. Rout. Reading habits: An Overview. // IOSR Journal of Humanities and Social Science 14, 6(2013), str. 13. [citirano: 2020-06-02]. Dostupno na: http:// www.iosrjournals.org/iosr-jhss/papers/Vol14-issue6/C01461317.pdf?id=6700.

${ }_{12}$ Usp. Sheldrick Ross, C. Reading interests. // Encyclopedia of Library and Information Sciences. 3rd ed. Taylor \& Francis, 2010., str. 2-7. [citirano:2021-06-09]. Dostupno na: https://www. researchgate.net/publication/258764077_Reading_Interests.

13 Usp. Walter, V. A. Public library service to children and teens: A Research agenda. // Library trends 51, 4 (2003), str. 575. [citirano: 2020-26-10]. Dostupno na: https://www.ideals.illinois. edu/bitstream/handle/2142/8488/librar? sequence $=1$.

14 Usp. IFLA-ine smjernice za narodne knjižnice. // Vjesnik bibliotekara Hrvatske 55, 1 (2012), str. $124-125$. 
od specifičnijih korisničkih skupina u knjižnicama zasigurno su mladi korisnici koje se često svrstava u istu skupinu s djecom ili odraslima te im se ne posvećuje dovoljno pozornosti kao zasebnoj skupini koja ima svoje potrebe i interese koji su različiti od dječjih ili onih odraslih. Razlog tome može se pronaći u dugoj tradiciji podjela unutar narodnih knjižnica na odjele za djecu i odjele za odrasle, zbog čega su se mladi, ovisno o svojim godinama, smjestili u jedan od tih odjela, što je često rezultiralo time da mladi u knjižnicama teško mogu naći literaturu i aktivnosti za sebe. Uz to, još jedan razlog zašto se u narodnim knjižnicama dugo nisu uvodile usluge i programi za mlade jest i problem određivanja pojma ,mladi“ $i$ dobnih granica koje obuhvaćaju tu korisničku skupinu, što pred knjižničare stavlja problem kako organizirati i koga sve uključiti u programe i usluge za mlade. U posljednjem desetljeću dvadesetog stoljeća u narodnim knjižnicama počelo se intenzivnije raditi s mladima. Na početak rada s mladima utjecale su pojave novih informacijskih i komunikacijskih tehnologija, ali i objava prvog izdanja IFLA-inih Smjernica za knjižnične usluge za mladež. Njemačke knjižnice bile su među prvim knjižnicama u Europi koje su uvele usluge za mlade. Međutim i Hrvatska prati razvoj knjižničarstva za mlade u Europi, te se već 2000. godine u Hrvatskoj otvara prvi odjel za mlade i to u Knjižnici Medveščak u Zagrebu. U organiziranju programa i otvaranju odjela i knjižnica za mlade, knjižničari su se počeli voditi mišlju da je mladima potrebno pristupiti kao zasebnoj korisničkoj skupini koja je usmjerena ne samo na čitanje već i na medije i tehnologiju te da im to treba ponuditi i u knjižnicama. Pri tome se razvija i mišljenje da mladi trebaju sudjelovati u procesu organiziranja usluga i programa koji se njima namjenjuju, pa glavno načelo rada s mladima postaje raditi s njima, a ne za njih. Mladima se knjižnične usluge mogu ponuditi kroz tri različita koncepta, a to su knjižnica za mlade, odjel za mlade i programi za mlade. Iako se navedeni koncepti razlikuju po smještaju, prostoru i načinu organiziranja, zajedničko im je upravo to da se mladi prepoznaju kao zasebna korisnička skupina koja ima drugačije informacijske i čitateljske potrebe, kao i potrebe u okviru provođenja slobodnog vremena. ${ }^{15}$ Neovisno o tome koji od navedenih triju koncepata knjižnica primjenjuje kada radi za mlade, knjižničari trebaju biti svjesni emocionalnog i fizičkog razvoja mladih te podržati promjene u njihovim interesima i potrebama. ${ }^{16}$ Šest je ključnih ciljeva na kojima bi knjižnica koja želi biti na usluzi mladima trebala raditi. Prvi je cilj provoditi usluge prikladne za potrebe mladih, ${ }^{17}$ zbog čega će porasti vjerojatnost da mladi knjižnicu vide kao mjesto na kojemu mogu pronaći potrebne informacije, ali i kao zabavno

15 Usp. Stričević, I.; S. Jelušić. Knjižnične usluge za mlade: Modeli i koncepti. // Vjesnik bibliotekara Hrvatske, 53, 1(2010), str. 1-19.

16 Usp. IFLA Professional Report.. Nav. dj., str. 2.

17 Usp. Gorman, M.; T. Suellentrio. Nav. dj., str. 3-8. 
mjesto za druženje te kao pozitivno i korisno okruženje. ${ }^{18}$ Dakle važno je naglasiti i važnosti društvene strane programa za mlade u knjižnicama, a ne se držati samo informacijske uloge jer upravo zbog toga mladi knjižnicu povezuju sa školom i zadaćom, što vrlo lako može rezultirati time da će mladi u slobodno vrijeme ići drugamo, a ne tamo gdje se i dalje osjećaju kao u školi. ${ }^{19}$ Drugi je cilj uključiti mlade u rad knjižnice kao volontere te osposobiti osoblje za rad s mladima, ${ }^{20}$ što će osigurati razvijanje programa i usluga prema interesima mladih, a uz to može i smanjiti jaz između knjižničnog osoblja i mladih ${ }^{21}$ koji često zna biti prisutan zbog raznih predrasuda i stereotipa o tome da su mladi neozbiljni i nezainteresirani za knjižnicu, a da su knjižničari neljubazni prema mladima te da je knjižnica dosadno mjesto u kojemu ne mogu pronaći ono što ih zanima. ${ }^{22}$ Treći je cilj ispunjavanje jedinstvenih potreba mladih, pri čemu treba prepoznati da mladi nisu ni odrasli, ni djeca, ${ }^{23}$ što upućuje na to da knjižničari trebaju biti upoznati s knjigama za mlade koje knjižnica posjeduje. Knjižnica bi, stoga, u nastojanju da ispuni sve čitateljske i informacijske potrebe mladih, trebala posjedovati knjige velikog raspona žanrova i tema - od ljubavne i kriminalističke fikcije do nefikcije koja se bavi raznim životnim problemima kao što su bolesti, samopomoći i sl. Kako bi znali koje knjige nabaviti, knjižničari trebaju razgovarati s mladima, ali i drugim knjižničarima te čitati članke i recenzije knjiga. ${ }^{24}$ Četvrti cilj odnosi se na prostor u knjižnici koji će biti opremljen i namijenjen samo mladima, ${ }^{25}$ a bilo bi poželjno da se u tom prostoru nalaze zbirke za tinejdžere, zatim održavaju aktivnosti i događaji te da u tom prostoru mladi mogu raditi na svojim zadacima, čitati, ali se i družiti s prijateljima te razgovarati s knjižničarima. Prostor za mlade trebao bi biti uočljiv odmah s ulaza knjižnice ili bi se trebali postaviti znakovi koji upućuju na to gdje se prostor za mlade nalazi kako bi oni znali da je knjižnica jedan svoj dio namijenila samo njima, a sve u tom prostoru treba biti prilagođeno mladima, od

18 Usp. Agosto, D. Why do teens use libraries?: Results of a public library use survey. // Public Libraries 46, 3 (2007), str. 60-61. [citirano: 2020-10-26]. Dostupno na: https://www.researchgate.net/publication/292710242_Why_do_teens_use_libraries_Results_of_a_public_library_use_ survey/link/5718bd0808ae30c3 3f9f1896 b/download.

19 Usp. Corradini, E. Teenagers analyse their public library. // New library world 107, 11/12 (2006), str. 494.

20 Usp. Gorman, M.; Suellentrio, T. Nav. dj., str. 3-8.

21 Usp. Snowball, C. Nav. dj., str. 27.

22 Usp. Corradini, E. Teens and library services: Experiences, expectations, perspectives: An Exploratory study: Dissertation proposal. University of Northumbria at Newcastle: University of Parma, 2004. Str. 3-4. [citirano: 2021-06-04]. Dostupno na: https://www.researchgate.net/ publication/33436328_Teens_and_library_services_experiences_expectations_perspectives_an exploratory_study_dissertation_proposal.

23 Usp. Gorman, M.; T. Suellentrio. Nav. dj., str. 3-8.

24 Usp. Mahood, K. A passion for print: Promoting reading and books to teens. Westport: Libraries Unlimited, 2006. Str. 35-60.

25 Usp. Gorman, M.; T. Suellentrio. Nav. dj., str. 3-8. 
promotivnih materijala do namještaja, tehnologije i dekoracija. Prostor za mlade ne bi trebao biti statičan, već se treba mijenjati kako se mijenjaju i nadopunjuju interesi, trendovi i knjižnične zbirke, a treba ga se održavati urednim, ali opet ne previše urednim kako ne bi djelovalo da se taj prostor nikada ne koristi. ${ }^{26}$ Peti je cilj omogućivanje jedinstvenih knjižničnih zbirki i izvora koji će pružiti potrebne informacije za obrazovanje i zabavu ${ }^{27}$ jer će takve zbirke koje nude obilje materijala pomoći u smanjivanju odbojnosti prema čitanju kod mladih koji mogu biti izbirljivi pri odabiru knjiga za čitanje iz zabave, ali će uživati u čitanju kada pronađu nešto s čime se mogu poistovjetiti. ${ }^{28}$ Šesti cilj podrazumijeva da knjižnice trebaju iskoristiti „stručnost“" mladih, odnosno njihovo iskustvo za poboljšanje usluga i programa knjižnice, ${ }^{29}$ a u rad ih se može uključiti tako da ih se pita za savjete ili organiziraju savjetodavne skupine. Takve skupine mogu pomoći knjižnici u planiranju aktivnosti, programa i usluga te njihovom ostvarivanju. ${ }^{30}$ Da bi se mogle stvoriti dobre knjižnične usluge za mlade, potrebno je uvažiti sve različitosti i potrebe mladih kako one informacijske i čitateljske tako i društvene, a u organizaciji usluga na umu treba imati i stil života i kulturu mladih. Narodna knjižnica treba ići ususret potrebama mladih i mijenjati se tako da uvijek bude na usluzi mladima, a ne očekivati od mladih da se oni prilagođavaju i mijenjaju svoje interese i potrebe ovisno o tome kakve usluge knjižnica nudi. ${ }^{31}$ Kako bi što učinkovitije ispunjavale čitateljske potrebe i interese mladih korisnika, knjižnice trebaju provoditi istraživanja upravo u području čitateljskih potreba i interesa koji će dati uvid u ono što mladi žele čitati i imati na raspolaganju u svojim lokalnim knjižnicama.

\section{Pregled ranijih istraživanja}

Istraživanja čitateljskih potreba $\mathrm{i}$ interesa te zadovoljstva mladih lokalnim knjižnicama, uslugama i programima koje pružaju važna su jer rezultati takvih istraživanja mogu pomoći knjižnicama da što učinkovitije odgovaraju na čitateljske potrebe mladih i organiziraju događaje koji će mladima biti zanimljivi, koje će posjećivati i u kojima će rado sudjelovati. Kada se govori o motivaciji za čitanje iz užitka, rezultati jednog kanadskog istraživanja pokazuju da mlade na čitanje iz užitka motivira to da im vrijeme brže prolazi kada čitaju, da ih to opušta, razvija maštu i obrazovanje te razne vještine. ${ }^{32}$ Zatim, jedno britansko istraživanje poka-

26 Usp. Mahood, K. Nav. dj., str. 65-78.

27 Usp. Gorman, M.; T. Suellentrio. Nav. dj., str. 3-8.

28 Usp. Snowball, C. Teenagers talking about reading and libraries. // Australian Academic \& Research Libraries 39, 2(2008), str. 106. [citirano: 2020-10-26]. Dostupno na: https://www.tandfonline.com/doi/abs/10.1080/00048623.2008.10721336.

29 Usp. Gorman, M.; T. Suellentrio. Nav. dj., str. 3-8.

30 Usp. Snowball, C. Teenagers talking about reading and libraries, str. 26-27.

31 Usp. Stričević, I.; S. Jelušić. Nav. dj., str. 27.

32 Usp. Howard, V. The importance of pleasure reading in the lives of young teens: self-identification, self-construction and self-awareness. // Journal of Librarianship and Information 
zalo je da mladi kada ne čitaju za zabavu, čitaju jer im to pomaže razumjeti svijet, upoznati druge kulture $\mathrm{i}$ otkriti nešto novo. ${ }^{33}$ Nadalje, istraživanje provedeno $\mathrm{u}$ Indoneziji pokazalo je da mladi imaju pozitivan stav prema čitanju kada se radi o razvijanju raznih vještina čitanjem. Ispitanici tog istraživanja smatraju da im čitanje poboljšava gramatičke vještine, vokabular i znanje općenito, a u isto vrijeme pruža im i zabavu. ${ }^{34}$ Usporede li se rezultati istraživanja provedenih u Velikoj Britaniji, Indoneziji i Hrvatskoj, može se zaključiti da mladi diljem svijeta imaju slične interese kada su u pitanju žanrovi koje vole čitati, pa su tako među omiljenim žanrovima izdvojena avanturistička djela, komedije, horori, kriminalističke i ljubavne priče te znanstvena-fantastika i fantazija. ${ }^{35}$ Također, pogledaju li se rezultati istraživanja provedenih u Sjevernoj Karolini i Jugozapadnoj Engleskoj, može se uočiti da većina mladih voli čitati priče koje sadrže likove s kojima se mogu poistovjetiti i koje govore o svakodnevnim problemima i situacijama u kojima su se i sami našli tijekom svog života. ${ }^{36}$

Što se tiče odnosa mladih i knjižnice, dva američka istraživanja pokazala su da mladi u knjižnicu većinom dolaze jednom tjedno te da u knjižnicu dolaze kako bi pronašli informacije vezane uz školu i slobodno vrijeme, ali i da bi se družili i zabavljali na raznim programima ili kako bi se odmakli od buke svakodnevnog života jer knjižnicu vide kao pozitivno okruženje za provođenje slobodnog vremena, ${ }^{37}$ dok je istraživanje provedeno u Italiji pokazalo da kod mladih ulogu u posjećivanju knjižnice često ima i utjecaj vršnjaka jer ako „popularni“ prijatelji kažu da nije zanimljivo ići u knjižnicu, velika je vjerojatnost da ostatak grupe neće odlaziti u knjižnicu u slobodno vrijeme kako bi se uklopili u navedeno društvo. ${ }^{38} \mathrm{~S}$ druge strane, istraživanja provedena u Iranu, Australiji i na Floridi pokazala su da mladi na tim područjima knjižnicu većinom posjećuju zbog učenja, pisanja zadaće i po-

Science 43, 1(2011), str. 49. [citirano: 2020-06-02]. Dostupno na: https://journals.sagepub.com/ doi/10.1177/0961000610390992.

33 Clark, K.; A. Foster. Children's and young people's reading habits and preferences: The Who, what, why, where and when. // Nationa Literacy Trust (2005), str. 48. [citirano: 2020-08-17]. Dostupno na: https://files.eric.ed.gov/fulltext/ED541603.pdf.

34 Usp. Maharasi, I.; S. Maulani. Nav. dj., str. 82.

35 Usp. Clark, K.; A. Foster. Nav. dj., str. 51.; Također usp. Maharasi, I.; S. Maulani,. Nav. dj., str. 82.; Sabolović-Krajina, D. Čitateljske navike tinejdžera u Hrvatskoj. [citirano: 2021-06-02]. Dostupno na: http://dzs.ffzg.unizg.hr/text/sabolovic-krajina_1993.htm.

36 Usp. Moeller, R. A.; K. E. Becnel. You are what you read: Young adult literacy and identity in rural America. // YRLA 6(2015), str. 10-14. [citirano: 2020-06-12]. Dostupno na: http://www.yalsa.ala.org/jrlya/wp-content/uploads/2015/04/You-Are-What-You-Read_Final.pdf.; Također usp. i Hopper, R. What are teenagers reading?: Adolescent fiction reading habits and reading choices. // Literacy 39, 3(2005), str. 116. [citirano: 2020-08-17]. Dostupno na: https://onlinelibrary.wiley. com/doi/epdf/10.1111/j.1467-9345.2005.00409.x.

37 Usp. Agosto, D. Nav. dj., str. 58-60.; Također usp. Cook, S. J.; R. S. Parker; C. E. Pettijohn. Young teens and the public library: An American investigation. [citirano: 2020-10-26]. Dostupno na: https://bbf.enssib.fr/consulter/bbf-2008-06-0081-003.

38 Usp. Corradini, E. Nav. dj., 2006, str. 491-493. 
sudbe knjiga potrebnih za školu i posudbe ostale stručne literature. ${ }^{39}$ Nadalje, jedno kanadsko istraživanje pokazalo je da većina mladih ne koriste usluge knjižnice iako su u nju učlanjeni, a razlog tome je što knjižnica nema dovoljno računala, ne nudi zanimljive programe ili mladi nisu upoznati s programima koje knjižnica provodi. Uz to rok posudbe od tri tjedna im je prekratak da pročitaju posuđene knjige. Također smatraju da bi više posjećivali knjižnicu kada bi na vrijeme znali za događaje koje knjižnica organizira. ${ }^{40}$ Mladi koji su sudjelovali u istraživanju provedenom u Philadelphiji također su naveli da ne posjećuju knjižnice jer one nemaju dovoljno usluga za mlade te im se ne sviđaju neki aspekti knjižnice, npr. stroga pravila, turoban prostor, ograničen pristup tehnologiji te su često dojma da je osoblje neljubazno prema njima. ${ }^{41}$ Istraživanje provedeno u Iranu pokazalo je da knjižnica većinom ispunjava potrebe vezane uz školske obaveze, dok u manjoj količini ispunjava potrebe povezane s čitanjem iz užitka, te su mladi istaknuli kako im se ne sviđa radno vrijeme knjižnice i to što ne mogu pronaći dovoljno knjiga koje im se sviđaju. ${ }^{42}$

Kada govorimo o tome što bi mlade privuklo u knjižnicu, rezultati istraživanja provedenih na Floridi, u Italiji i Australiji pokazali su da bi mlade u knjižnicu moglo privući to da ih se uključi u rad knjižnice, povećanje knjižnične zbirke namijenjene njima, organiziranje zabavnih programa, literarne grupe, novija tehnologija, bolje radno vrijeme, više osoblja, a ponajviše udoban prostor te hrana i piće. ${ }^{43} \mathrm{U}$ istraživanju provedenom u Kanadi mladi su također naglasili važnost udobnog prostora namijenjenog samo njima, koji će ispuniti njihove informacijske i društvene potrebe, ali da se i trenutno osjećaju dobrodošlima u knjižnici i da je osoblje uvijek ljubazno prema njima iako ih ne traže pomoć često jer im knjižničari djeluju prezaposleno. ${ }^{44}$ Slične rezultate pokazala su istraživanja provedena u Australiji i

39 Usp. Asemi, A. A survey on the teenagers' need of public libraries' resources and services (LRs \& LSs). // Journal of libray \& information technology 38, 4 (2018), str. 296-297. [citirano: 2020-10-26]. Dostupno na: https://pdfs.semanticscholar.org/d234/8b46c265f32da511c2a0db426e5516943968.pdf.; Također usp. i Bishop, K; P. Bauer. Attracting young adults to public libraries: Frances Henne/YALSA/VOYA research grant results. // Journal of Youth Services in Libraries 15, 2 (2002), str. 41.; Fisher, H. A teenage view of the public library: What are the students saying? // APLIS 16, 1(2003) str. 6-10. [citirano: 2020-10-26]. Dostupno na: https://search. informit.org/doi/abs/10.3316/ielapa.971882240794092

40 Usp. Howard, V. What do young teens think about the public library? // The library quaterly 81, 3(2011), str. 327-355. [citirano: 2020-10-26]. Dostupno na: https://www.jstor.org/stable/10.1086/660134? origin=JSTOR-pdf.

${ }^{41}$ Usp. Agosto, D.; S. Hughes-Hasell. People, places, and questions: An Investigation of the everyday life information-seeking behaviors of urban young adults. // Library \& Information Science Research 27 (2005), str. 151-161. [citirano: 2020-10-26]. Dostupno na: https://www. sciencedirect.com/science/article/abs/pii/S0740818805000046.

42 Usp. Asemi, A. Nav. dj., str. 298-300.

43 Usp. Bishop, K; P. Bauer. Nav. dj., str. 39-40.; Također usp. Corradini, E. Nav. dj., 2006., str. 492.; Također usp. i Fisher, H. Nav. dj., str. 7.

44 Usp. Howard, V. Nav. dj., str. 330-342. 
Philadelphiji u kojima su mladi također istaknuli da su knjižničari uvijek ljubazni, ali $i$ to da bi trebali više znati o knjigama i autorima za mlade kao i o njihovim informacijskim potrebama i interesima kako bi im mogli bolje pomoći. ${ }^{45}$

\section{Istraživanje}

Istraživanje ${ }^{46}$ je provedeno s ciljem utvrđivanja čitateljskih navika, potreba $\mathrm{i}$ interesa učenika Gimnazije A. G. Matoša pri čitanju iz užitka. Uz to, željelo se utvrditi odgovara li Gradska knjižnica i čitaonica Đakovo (u daljnjem tekstu GKC̆ Đakovo) svojim uslugama i programima na potrebe i interese učenika te potiče li ih na čitanje iz užitka. U ovom radu prikazan je dio istraživanja koji se odnosi na čitateljske potrebe i interese učenika đakovačke gimnazije te ulogu GKČ Đakovo $\mathrm{u}$ ispunjavanju istih i u poticanju čitanja iz užitka.

\subsection{Cilj istraživanja}

Cilj je ovog istraživanja utvrditi koje i kakve čitateljske potrebe i interese učenici Gimnazije A. G. Matoša pri čitanju iz užitka imaju te odgovara li GKČ Đakovo i potiče li GKČ Đakovo učenike navedene gimnazije na čitanje iz užitka. Dobiveni rezultati pomažu prepoznati čitateljske potrebe i interese učenika, na temelju čega GKČ Đakovo može procijeniti koliko dobro ispunjava čitateljske potrebe i interese učenika i kako može poboljšati svoje usluge i programe da bi što učinkovitije odgovarala na potrebe i interese svojih mladih korisnika.

Istraživačka pitanja (IP):

1. Koje su čitateljske potrebe i interesi učenika pri čitanju iz užitka?

2. Koje čitateljske potrebe i interese učenika u kontekstu čitanja iz užitka ispunjava Gradska knjižnica i čitaonica Đakovo?

3. Potiče li Gradska knjižnica i čitaonica Đakovo čitanje iz užitka kod učenika?

45 Usp. Fisher, H. Nav. dj., str. 9-12.; Također usp. i Agosto D.; S. Hughes-Hasell. Nav. dj., str. $150-151$.

46 Ovo istraživanje dio je istraživanja provedenog za potrebe izrade diplomskog rada „Čitateljske navike, potrebe i interesi učenika Gimnazije A. G. Matoša u Đakovu“" pod mentorskim vodstvom I. Martinović. 


\subsection{Metodologija}

\subsubsection{Metoda $\mathrm{i}$ instrument}

$\mathrm{U}$ ovom istraživanju primijenjena je kvantitativna metoda, odnosno metoda anketiranja. Anketiranje je zbog pandemije bolesti COVID 19 i nemogućnosti provedbe kontaktno, provedeno online. U radu su prikazani podaci prikupljeni s deset pitanja u anketnom upitniku ${ }^{47}$, a koja odgovaraju na navedena istraživačka pitanja. U uvodnom dijelu anketnog upitnika učenicima je objašnjeno tko i zašto provodi istraživanje. Nakon toga slijedi deset pitanja, od kojih većina sadrži i potpitanja, a koja se mogu razlikovati ovisno o tome što su učenici odgovorili u pitanju koje prethodi određenom potpitanju. Zbog toga se i konačan broj pitanja na koja su ispitanici odgovorili razlikuje, jer se, ovisno o odgovoru, otvara različit broj potpitanja za određeno pitanje.

\subsubsection{Uzorak}

Anketni upitnik ispunilo je 75 učenika, 57 (76 \%) ispitanika je ženskog spola, a 18 (24 \%) ispitanika je muškog spola. Ispitanici imaju između 15 i 18 godina. Najviše je onih koji imaju 18 godina (30,7\%), a najmanje onih s 19 godina (4\%). Jednak broj ispitanika ima 15 i 17 godina (21,3\%), a gotovo jednako ispitanika ima 16 godina $(22,7 \%)$. Od ukupnog broja ispitanika, najviše njih polazi četvrti razred (33,3\%), zatim prvi razred (24\%), drugi razred (22,7\%) i treći razred (20\%).

\subsubsection{Postupak}

Istraživanje je provedeno u Gimnaziji A. G. Matoša u Đakovu tijekom svibnja 2020. godine. Za provođenje istraživanja prvo je zatraženo odobrenje ravnatelja đakovačke gimnazije, nakon čega je izrađen online anketni upitnik. Zatim su kontaktirani razrednici dvaju odjela svih razreda kako bi ih se zatražilo dopuštenje da se anketa provede u njihovom odjelu. Dopuštenje je dobiveno za dva odjela prvog, drugog i četvrtog razreda te za jedan odjel trećeg razreda. Zbog problema sa stupanjem u kontakt s drugim razrednicima trećih razreda, u uzorak je ušao samo jedan razredni odjel 3. razreda. Razrednicima je proslijeđena poveznica na anketni upitnik te na obrazac suglasnosti za roditelje, u kojem su roditelji trebali dati suglasnost za sudjelovanje njihovog djeteta u istraživanju. U trenutku pisanja rada, nastava se odvijala online,$^{48}$ pa su razrednici poveznice učenicima proslijedili u virtualne učionice.

\footnotetext{
47 Cijeli anketni upitnik, oblikovan za potrebe diplomskog rada, sastoji se od uvodnog dijela i dvadeset pitanja.

48 Tijekom provedbe istraživanja, u proljeće 2020. godine, nastava se odvijala online u virtualnim učionicama zbog proglašene pandemije bolesti COVID-19.
} 


\subsection{Rezultati}

Kako bi se dobio odgovor na prvo istraživačko pitanje u anketnom upitniku postavljena su pitanja otvorenog i zatvorenog tipa, a sadržajno su se odnosila na čitanje, motivaciju za čitanje, najčitanije žanrove i teme, učestalost čitanja knjiga domaćih i stranih autora te na najdraže pisce i djela. Rezultati su pokazali da je čitanje za ispitanike bijeg od stvarnosti, opuštanje te „uplovljavanje“ u neki drugi svijet. Uz to, smatraju da je čitanje jedan od načina za razvijanje mašte te zabava kada čitaju ono što žele, ali obaveza i gubitak vremena kada čitaju ono što moraju, npr. lektiru. Nekoliko je onih koji smatraju da je čitanje dosadno i da je to samo školska obaveza te ne mogu razumjeti osobe koje čitaju za zabavu, ali s druge strane puno ispitanika navelo je da im je čitanje istovremeno i zabava i učenje nečeg novog, razvijanje kritičkog mišljenja, pogleda na svijet, proširivanje vokabulara i slično. Neki čitanje smatraju čak, halucinacijom iznad knjige, oblikom meditacije, razvijanjem u emocionalnom smislu i odlično iskorištenim slobodnim vremenom. Kada govorimo o motivaciji za čitanjem, ispitanike na čitanje najviše motiviraju zabava i opuštanje $(62,7 \%)$ i bijeg od stvarnosti $(57,3 \%)$. Zatim sadržaj teksta $(54,7 \%)$, učenje nečeg novog $(46,7 \%)$, želja za razvijanjem vještina čitanja i vokabulara te pisanja $(42,7 \%)$, višak slobodnog vremena $(21,3 \%)$, okolina i socijalno prihvaćanje (1,3\%). Samo je 4 (5,3\%) ispitanika upisalo svoj odgovor te su naveli da ne vole čitati pa čitaju samo lektiru ili kratke tekstove na internetu. Rezultati su prikazani u tablici 1.

Tablica 1. Motivacija ispitanika za čitanje

\begin{tabular}{|l|c|c|}
\hline Motivacija za čitanje & $\mathbf{N}$ & $\mathbf{\%}$ \\
\hline Bijeg od stvarnosti & 43 & $57,3 \%$ \\
\hline Okolina i socijalno prihvaćanje & 1 & $1,3 \%$ \\
\hline Višak slobodnog vremena & 16 & $21,3 \%$ \\
\hline $\begin{array}{l}\text { Želja za razvijanjem vještina } \\
\text { čitanja i vokabulara te pisanja }\end{array}$ & 32 & $42,7 \%$ \\
\hline Sadržaj teksta & 41 & $54,7 \%$ \\
\hline Učenje nečeg novog & 35 & $46,7 \%$ \\
\hline Zabava i opuštanje & 47 & $62,7 \%$ \\
\hline
\end{tabular}

Rezultati su također pokazali da najviše ispitanika voli čitati ljubavni (64 \%) i kriminalistički žanr (60\%). Manje od polovice ispitanika voli čitati dnevnike (41,3\%), zatim avanturistički žanr (40\%), fantastiku (29,3\%), znanstvenu-fantastiku (28 \%), povijesni žanr (12\%), autobiografiju i biografiju (9,3\%). Devet je 
ispitanika (12\%) pod Ostalo navelo da vole čitati horor, filozofsku i medicinsku literaturu. Rezultati su prikazani u tablici 2.

Tablica 2. Žanrovi koje ispitanici najviše vole čitati

\begin{tabular}{|l|c|c|}
\hline Žanr & $\mathbf{N}$ & $\mathbf{\%}$ \\
\hline Autobiografija & 7 & $9,3 \%$ \\
\hline Avanturistički & 30 & $40 \%$ \\
\hline Biografija & 7 & $9,3 \%$ \\
\hline Dnevnici & 31 & $41,3 \%$ \\
\hline Fantastika & 22 & $29,3 \%$ \\
\hline Kriminalistički & 45 & $60 \%$ \\
\hline Ljubavni & 48 & $64 \%$ \\
\hline Povijesni & 9 & $12 \%$ \\
\hline Znanstvena-fantastika & 21 & $28 \%$ \\
\hline
\end{tabular}

Kada se radi o temama koje ispitanici najviše vole čitati, rezultati su pokazali da većina ispitanika voli čitati o temama s likovima s kojima se mogu poistovjetiti (66,7 \%), o svakodnevnim poteškoćama (54,7 \%) i svladavanju izazova $(50,7 \%)$, zatim o ljubavnim problemima (49,4\%) i prijateljstvu (46,7 \%), dok manje ispitanika voli čitati o temama s problemom zlostavljanja ( $28 \%)$, suočavanju sa smrti bliske osobe (24\%), problemu siromaštva $(17,3 \%)$, sportu (14,7\%), pravima žena $(13,3 \%)$ i obrazovanju ( $8 \%)$. Deset ispitanika (13,3\%) je uz odabrane ponuđene odgovore napisalo i svoj odgovor te navelo da voli čitati i stručnu literaturu te o životima tinejdžera, glazbi i povijesti. Rezultati su prikazani u tablici 3.

Tablica 3. Teme o kojima ispitanici najviše vole čitati

\begin{tabular}{|l|c|c|}
\hline Teme & N & \% \\
\hline Ljubavni problemi & 37 & $49,4 \%$ \\
\hline Obrazovanje & 6 & $8 \%$ \\
\hline Prava žena & 10 & $13,3 \%$ \\
\hline Prijateljstvo & 35 & $46,7 \%$ \\
\hline Problem siromaštva & 13 & $17,3 \%$ \\
\hline Problem zlostavljanja & 21 & $28 \%$ \\
\hline
\end{tabular}




\begin{tabular}{|l|l|c|}
\hline Teme & N & \% \\
\hline Sport & 11 & $14,7 \%$ \\
\hline Suočavanje sa smrti bliske osobe & 18 & $24 \%$ \\
\hline Svakodnevne poteškoće & 41 & $54,7 \%$ \\
\hline Svladavanje izazova & 38 & $50,7 \%$ \\
\hline Teme s likovima s kojima se mogu poistovjetiti & 50 & $66,7 \%$ \\
\hline
\end{tabular}

Rezultati istraživanja ukazuju na to da najveći postotak mladih rijetko i nikada ne čita domaće autore (68\%), ponekad ih čita (24\%), a rijetki su oni koji ih čitaju često $(6,7 \%)$ i vrlo često $(1,3 \%)$. S druge strane, najviše je ispitanika koji ponekad $(26,7 \%)$ čitaju knjige stranih autora. Nešto je manje onih koji ih čitaju vrlo često $(22,7 \%)$, često $(21,3 \%)$ i rijetko $(20 \%)$, a onih koji ih nikada ne čitaju je vrlo malo (9,3\%). Rezultati su prikazani u tablici 4.

Tablica 4. Učestalost čitanja knjiga domaćih i stranih autora

\begin{tabular}{|l|l|l|}
\hline Učestalost & $\begin{array}{l}\text { Učestalost čitanja knjiga } \\
\text { domaćih autora }\end{array}$ & $\begin{array}{l}\text { Učestalost čitanja knjiga } \\
\text { stranih autora }\end{array}$ \\
\hline Vrlo često & $1.3 \%$ & $22.7 \%$ \\
\hline Često & $6.7 \%$ & $21.3 \%$ \\
\hline Ponekad & $24 \%$ & $26.7 \%$ \\
\hline Rijetko & $42.7 \%$ & $20 \%$ \\
\hline Nikada & $25.3 \%$ & $9.3 \%$ \\
\hline
\end{tabular}

Ispitanici su mogli obrazložiti zašto češće čitaju knjige domaćih ili stranih autora u potpitanju otvorenog tipa, a naveli su da knjige stranih autora češće čitaju jer su raznolikije i zanimljivijih tema i stila pisanja te zbog veće popularnosti i zastupljenosti autora u medijima, ali i zbog boljeg marketinga, dok knjige domaćih autora ne čitaju često jer nisu upoznati s njima. Nekoliko je ispitanika navelo da knjige domaćih autora voli čitati jer su pisane razumljivijim stilom i sadrže likove s kojima se mogu lakše poistovjetiti, pa su im zbog toga knjige domaćih autora zabavnije. Nekim ispitanicima nije bitan autor knjige već im je važno samo da im se sviđa radnja. U jednom od zanimljivijih obrazloženja navedeno je da su knjige stranih autora prisutnije i više reklamirane od knjiga domaćih autora, pa čitatelji prije posežu za tim knjigama ne dajući priliku domaćim autorima. Nadalje, rezultati istraživanja ukazuju na to da puno mladih nema najdražeg pisca, a odgovori ostalih ispitanika poprilično su se razlikovali. Više puta spomenuti 
su John Green, Agatha Christie, Fjodor Mihajlovič Dostojevski, J. K. Rowling i Jenny Han, a istaknute su i domaće autorice Sanja Pilić, Sanja Polak i Vlasta Golub kao najdraže. Nadalje, manje je onih koji nemaju najdražu knjigu u odnosu na najdražeg pisca, a kao najdraže knjige više puta spomenute su sljedeće: Mali princ, Greška u našim zvijezdama, Zločin i kazna, Ana Karenjina i Ubojstvo u Orient Expressu. Spomenute su i knjige domaćih autora poput Koko u Parizu i Skijaški dnevnik Pauline P.

U svrhu dobivanja odgovora na drugo istraživačko pitanje postavljena su pitanja otvorenog i zatvorenog tipa, a odnosila su se na članstvo u narodnoj knjižnici, potrebu za čitanjem iz užitka i aktivnostima vezanima uz čitanje iz užitka koje GKČ Đakovo nudi. Rezultati istraživanja pokazali su da je većina ispitanika učlanjena u knjižnicu (50,7 \%) ili se koristi iskaznicom člana obitelji (24\%), dok je manje onih koji nisu članovi knjižnice $(25,3 \%)$. Rezultati su prikazani na slici 1 .

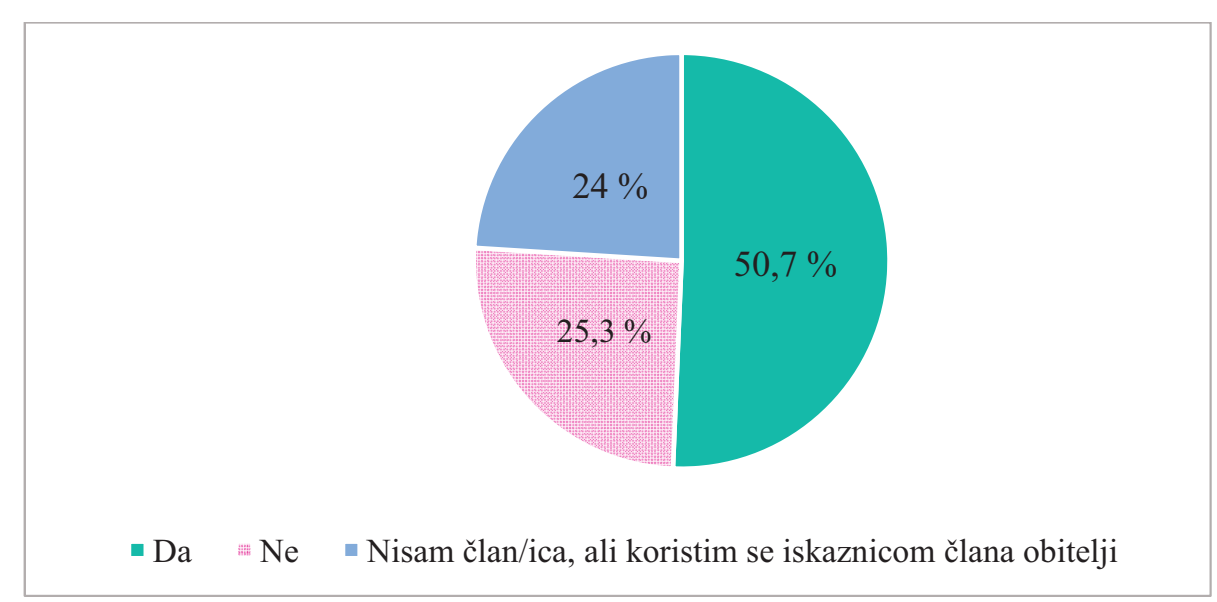

Slika 1. Grafikon članstva ispitanika u Gradskoj knjižnici i čitaonici Đakovo

Ispitanici koji nisu članovi knjižnice trebali su odgovoriti je li nešto od ponuđenih izjava razlog zašto nisu učlanjeni u knjižnicu. Većina ispitanika nije odabrala ponuđenu izjavu, već se odlučila napisati svoj odgovor (84,2 \%), a naveli su da ne čitaju knjige u slobodno vrijeme, da im je knjižnica izvan mjesta stanovanja, da im je dovoljna školska knjižnica ili da knjige kupuju. Samo jedan ispitanik (5,3\%) odabrao je izjavu Nemogućnost dobivanja preporuke za knjige prema mojim interesima, a dva ispitanika (10,5\%) odabrala su izjavu u Gradskoj knjižnici ne mogu pronaći knjige autora koje želim čitati. Ostale ponuđene izjave nije odabrao niti jedan ispitanik. Rezultati su prikazani u tablici 5. 
Tablica 5. Razlog zašto ispitanici nisu član Gradske knjižnice i čitaonice Đakovo

\begin{tabular}{|l|c|c|}
\hline $\begin{array}{l}\text { Razlog zašto ispitanici nisu član Gradske knjižnice i } \\
\text { čitaonice Đakovo }\end{array}$ & N & $\%$ \\
\hline $\begin{array}{l}\text { U Gradskoj knjižnici ne mogu pronaći knjige autora koje želim } \\
\text { čitati. }\end{array}$ & 2 & $10,5 \%$ \\
\hline $\begin{array}{l}\text { U Gradskoj knjižnici ne mogu pronaći knjige žanrova koje } \\
\text { želim čitati. }\end{array}$ & 0 & $0,00 \%$ \\
\hline $\begin{array}{l}\text { U Gradskoj knjižnici ne mogu pronaći knjige s temama koje } \\
\text { želim čitati. }\end{array}$ & 0 & $0,00 \%$ \\
\hline $\begin{array}{l}\text { Gradska knjižnica ne omogućuje pristup e-knjigama koje } \\
\text { želim čitati. }\end{array}$ & 0 & $0,00 \%$ \\
\hline $\begin{array}{l}\text { Nemogućnost dobivanje preporuke za knjige prema mojim } \\
\text { interesima. }\end{array}$ & 1 & $5,3 \%$ \\
\hline $\begin{array}{l}\text { Knjižnica ne organizira aktivnosti koje me zanimaju (npr. } \\
\text { radionice, predavanja, susreti s književnicima, klubovi } \\
\text { čitatelja i književnika i sl.) }\end{array}$ & 0 & $0,00 \%$ \\
\hline
\end{tabular}

Nadalje, rezultati su pokazali da ispitanici koji nisu članovi knjižnice svoje potrebe za čitanjem najčešće ispunjavaju kupovinom knjiga (63,2 \%), da ne čitaju knjige iz zabave (26,3\%) ili da ih čitaju online (21,1\%), da ih čitaju na vlastitom $e$-čitaču $(15,8 \%)$ te da svoje potrebe za čitanjem ispunjavaju u školskoj knjižnici $(15,8 \%)$. Samo je jedan ispitanik dao svoj odgovor i naveo da potrebe za čitanjem ispunjava kod kuće. Rezultati su prikazani u tablici 6.

Tablica 6. Ispunjavanje potreba za čitanjem iz užitka

\begin{tabular}{|l|c|c|}
\hline Ispunjavanje potreba za čitanjem iz užitka & $\mathbf{N}$ & $\mathbf{\%}$ \\
\hline U školskoj knjižnici. & 3 & $15,8 \%$ \\
\hline Kupujem knjige koje želim čitati. & 12 & $63,2 \%$ \\
\hline Čitam knjige na vlastitom e-čitaču (ili računalu, mobitelu). & 3 & $15,8 \%$ \\
\hline Čitam knjige online. & 4 & $21,1 \%$ \\
\hline Ne čitam knjige iz zabave, užitka. & 5 & $26,3 \%$ \\
\hline
\end{tabular}

Prema rezultatima istraživanja vidljivo je da knjižnica na čitateljske potrebe svojih članova i onih koji se koriste iskaznicom člana obitelji u najvećoj mjeri odgovora posjedovanjem knjiga žanrova i knjiga s temama koje žele čitati (83,9\%), 
zatim da knjižnica posjeduje knjige autora koje žele čitati (69,6 \%), da u knjižnici mogu dobiti preporuku u skladu s njihovim interesima $(35,7 \%)$ i da knjižnica omogućuje pristup elektroničkoj građi koju žele čitati (25\%). Samo jedan ispitanik (1,8 \%) dao odgovorio je da u knjižnici posuđuje samo lektire. Rezultati su prikazani u tablici 7.

Tablica 7. Potrebe na koje odgovara Gradska knjižnica i čitaonica Đakovo

\begin{tabular}{|l|c|c|}
\hline Potrebe na koje odgovora Gradska knjižnica i čitaonica Đakovo & N & \% \\
\hline Knjižnica posjeduje knjige autora koje želim čitati. & 39 & $69,6 \%$ \\
\hline Knjižnica posjeduje knjige žanrova koje želim čitati. & 47 & $83,9 \%$ \\
\hline Knjižnica posjeduje knjige s temama koje želim čitati. & 47 & $83,9 \%$ \\
\hline $\begin{array}{l}\text { Knjižnica omogućuje pristup elektroničkoj građi koju želim čitati } \\
\text { (npr. } \text { e-knjigama na } \text {-čitačima). }\end{array}$ & 14 & $25 \%$ \\
\hline $\begin{array}{l}\text { U knjižnici mogu dobiti preporuku za knjigu prema svojim } \\
\text { interesima. }\end{array}$ & 20 & $35,7, \%$ \\
\hline Ništa od navedenog. & 0 & $0,00 \%$ \\
\hline
\end{tabular}

Nadalje, ispitanici koji su članovi knjižnice ili koriste iskaznicu člana obitelji prema rezultatima istraživanja u velikom postotku ne sudjeluju u aktivnostima koje nudi Gradska knjižnica i čitaonica Đakovo, a koje su povezane s čitanjem iz užitka (69.6\%), a više od dvostruko manje je onih koji sudjeluju (30.4\%). Rezultati su prikazani na slici 2 .

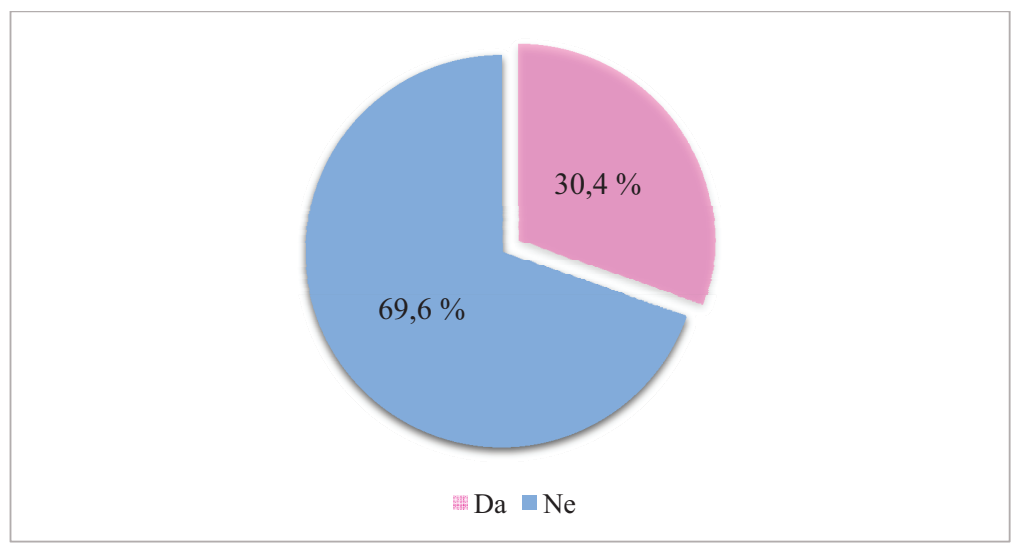

Slika 2. Grafikon sudjelovanja ispitanika u aktivnostima povezanim s čitanjem iz užitka koje nudi Gradska knjižnica i čitaonica Đakovo 
Ispitanici koji sudjeluju u aktivnostima povezanima s čitanjem iz užitka koje nudi GKČ Đakovo u potpitanju otvorenog tipa trebali su navesti u kojoj aktivnosti sudjeluju i što ih je na to potaknulo. Većina ispitanika odgovorila je da ne sudjeluje u takvim aktivnostima (76,5 \%), što znači da prethodno pitanje ili nisu razumjeli ili nisu pročitali do kraja. Ostali ispitanici $(23,5 \%)$ odgovorili su da sudjeluju u čitanju poezije, predstavljanju novih knjiga, klubu pisaca i literarnim radionicama. $\mathrm{S}$ druge strane, prema rezultatima istraživanja, za ispitanike koji ne sudjeluju u aktivnostima povezanim s čitanjem iz užitka u GKČ Đakovo ni ne postoji aktivnost vezana uz čitanje koju bi željeli posjetiti te za njih nemaju vremena, a neki od ispitanika su čak istaknuli i da su čitanje i vezane aktivnosti nešto što ne žele dijeliti s drugima. Navedeno je tek nekoliko prijedloga za aktivnosti vezane uz čitanje, koje bi GKČ Đakovo mogla organizirati, a to su više predstavljanja knjiga poznatijih autora i rasprave o stripovima. Uz to, ispitanike koji ne sudjeluju u aktivnostima koje nudi GKČ Đakovo na sudjelovanje u takvim aktivnostima potaknulo bi sudjelovanje njihovih prijatelja $(71,8 \%)$, zanimljivost programa $(61,5 \%)$, zatim način provođenja programa $(30,7 \%)$ i vrijeme održavanja programa $(15,4 \%)$. Dva ispitanika $(5,1 \%)$ odgovorila su da ne bi sudjelovali u takvim aktivnostima. Rezultati su prikazani na slici 3.

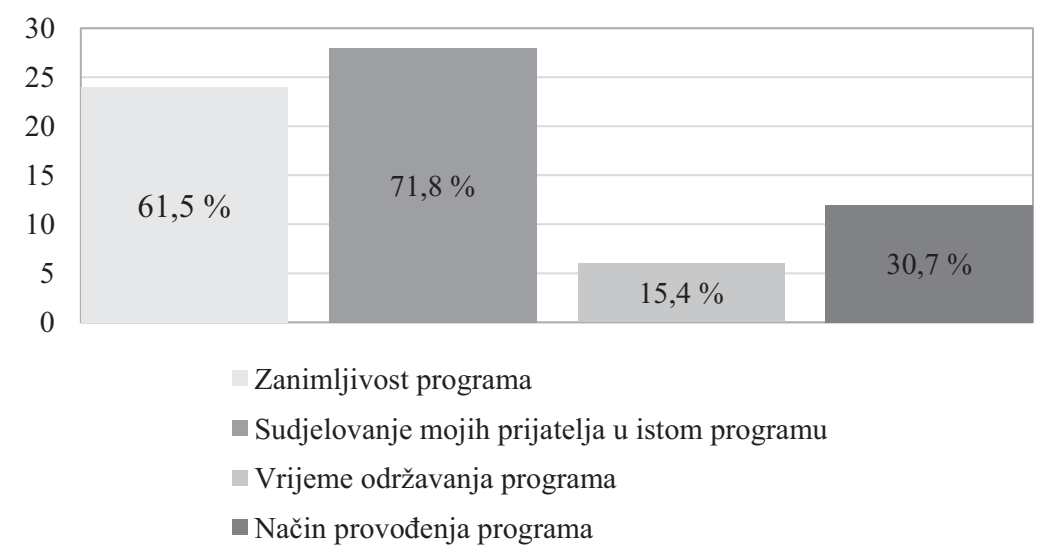

Slika 3. Grafikon poticaja na sudjelovanje u aktivnostima povezanim s čitanjem

U svrhu dobivanja odgovora na treće istraživačko pitanje postavljena su pitanja otvorenog i zatvorenog tipa, a odnosila su se na poticanje čitanja u knjižnici i što konkretno GKČ Đakovo može učiniti u tom području. Rezultati su pokazali da GKČ Đakovo većinu ispitanika niti potiče, niti ne potiče na čitanje iz užitka (64\%), zatim da ne potiče (20\%), dok je najmanje onih koje potiče (16\%). Rezultati su prikazani na slici 4 . 


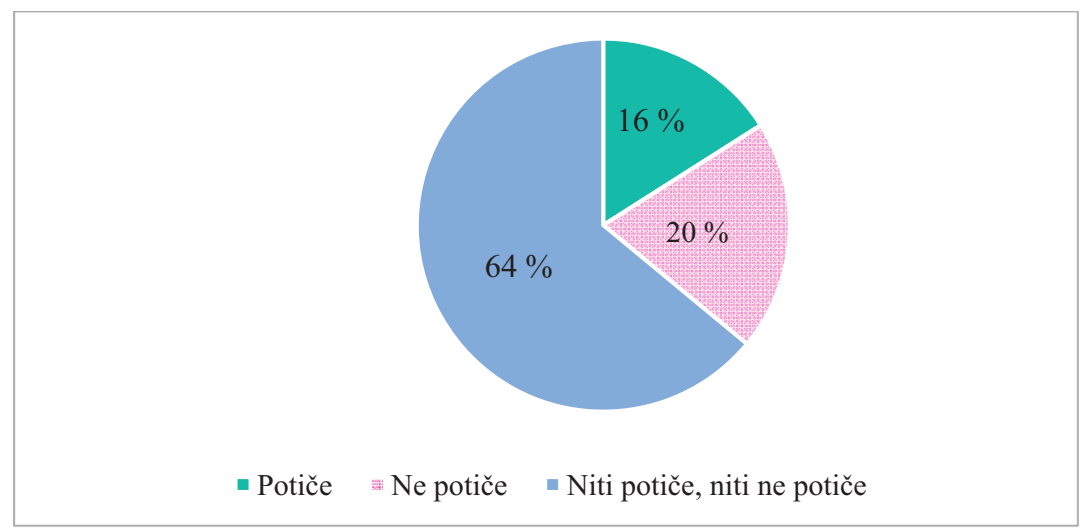

Slika 4. Grafikon poticanja ispitanika na čitanje iz užitka od strane Gradske knjižnice i čitaonice Đakovo I

Nadalje, najviše ispitanika (78,7 \%) odgovorilo je da ne zna potiče li GKČ Đakovo učenike dovoljno na čitanje, dok je puno manje onih koji su odgovorili da potiče dovoljno (16\%). Najmanje ispitanika smatra da GKČ Đakovo ne potiče učenike dovoljno na čitanje (5,3\%). Rezultati su prikazani na slici 5.

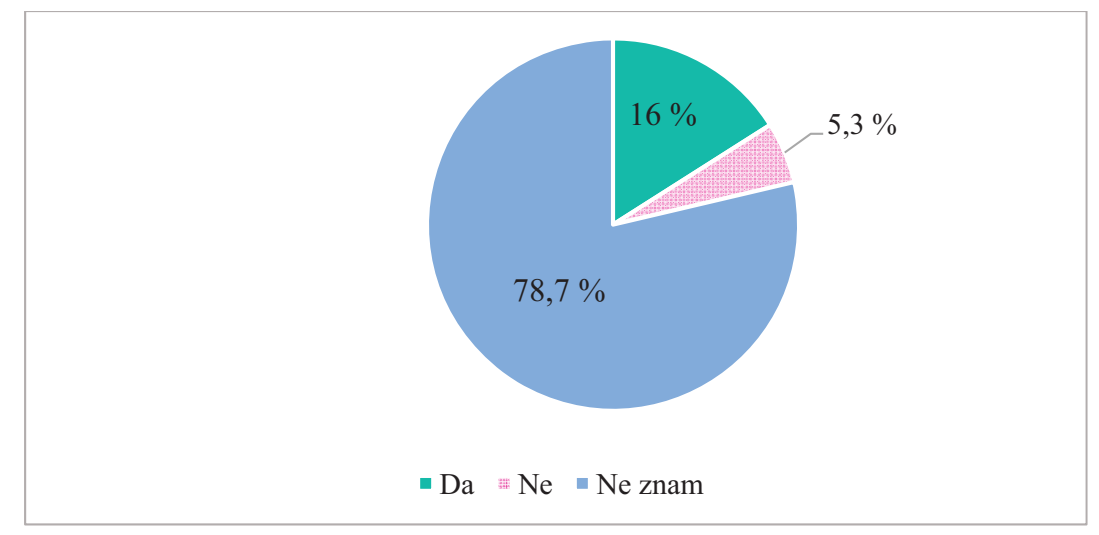

Slika 5. Grafikon poticanja ispitanika na čitanje iz užitka od strane Gradske knjižnice i čitaonice Đakovo II

Ispitanici koji ne smatraju da GKČ Đakovo potiče dovoljno na čitanje iz užit$\mathrm{ka}$, u potpitanju otvorenog tipa trebali su dati prijedlog što bi GKČ Đakovo mogla još poduzeti kako bi učenike potaknula na čitanje iz užitka te su ispitanici odgovorili da ne znaju ili da trebaju zanimljivije programe, a jedan se odgovor posebno istaknuo: 
„, Gradska knjižnica tu ne može puno napraviti jer je zainteresiranost za čitanje ipak jedan od dijelova obrazovanja, kada bi se npr. uvelo obiteljsko čitanje knjige u prošlosti, dok nije bilo elektronike, čitanje bi još uvijek bilo u modi jer je to izvor informacija. Da se točnije izrazim, ne trebamo odbacit tehnologiju $i$ vratit se u prošlost, nego samo želim reći kako knjige više nemaju toliku važnost kao prije, a u toj situaciji, kao što sam maloprije spomenuo, Gradska knjižnica ne može učiniti gotovo ništa. "

\subsection{Rasprava $i$ zaključci o istraživanju}

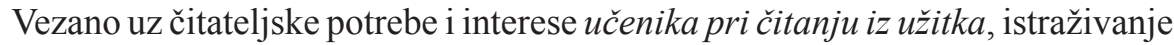
je pokazalo da mladi uključeni u istraživanje (konkretno đakovački gimnazijalci) prvenstveno čitaju zbog zabave, potaknuti bijegom od stvarnosti i opuštanjem, te da čitanje smatraju načinom za razvijanje mašte i zabavom, dok istovremeno razvijaju kritičko mišljenje, proširuju vokabular, poglede na svijet i slično. Upravo su opuštanje i razvijanje raznih vještina ono što ih najviše motivira na čitanje. Rezultati se podudaraju s istraživanjem autorice Howard (Kanada), dok se razlikuju od rezultata istraživanja autorica Clark i Foster (Velika Britanija). Različiti odgovori poimanja čitanja iz užitka i motivacije za čitanje mogu biti rezultat činjenice da je čitanje individualna aktivnost te da svatko za sebe u knjigama traži ono što mu je potrebno. Za neke je to zabava, a drugima stjecanje znanja o nečem novom.

Mladi najviše vole čitati ljubavne, kriminalističke i avanturističke priče te priče koje sadrže likove s kojima se mogu poistovjetiti, svakodnevne probleme i situacije u kojima su se našle osobe koje poznaju ili oni sami i ti su rezultati podudarni s rezultatima nekoliko istraživanja (Clark i Foster; Maharasi i Maulani; Moeller i Becnel; Sabolović-Krajina; Hopper), što znači da mladi diljem svijeta vole čitati priče sličnih tematika. Činjenica da mladi vole čitati priče koje govore o problemima s kojima se i sami susreću ne iznenađuje jer se nalaze u osjetljivom razdoblju, pa čitanje o likovima koji se susreću s istim tim problemima može im olakšati jer će dobiti potvrdu da nisu prvi ni jedni kojima se događa određeni problem ili pak prijedlog rješavanja određenog problema. Mladi vjerojatno vole čitati knjige takvih tema jer će radije pročitati nešto što ih zanima nego o tome razgovarati $\mathrm{s}$ nekim starijim. Prema rezultatima istraživanja, mladi više vole čitati knjige stranih nego domaćih autora za što je razlog, kako su i sami naveli, količina stranih autora i djela te raznolikost tema i zastupljenost u medijima. Ipak, kada ih se pitalo o najdražim autorima i knjigama, nekoliko ispitanika navelo je i domaće autore i knjige.

Odgovori na pitanja o čitateljskim potrebama i interesima učenika, $u$ kontekstu čitanja iz užitka koje ispunjava Gradska knjižnica i čitaonica Đakovo, pokazali su da je većina ispitanika član knjižnice ili da se koristi iskaznicom člana obitelji te 
da knjižnica ispunjava njihove čitateljske potrebe tako što posjeduje knjige žanrova, tema i autora koje ih zanimaju i koje žele čitati, što se podudara s rezultatima nekih istraživanja (Agosto; Cook, Parker, Pettijohn; Corradini) u kojima su mladi naveli da u knjižnicu ne idu samo zbog školskih obaveza i da knjižnica većinom ispunjava njihove potrebe. Ispitanici koji nisu članovi knjižnice naveli su da je razlog tome što ne čitaju knjige, činjenica što im je knjižnica predaleko te da svoje potrebe za čitanjem ispunjavaju u školskoj knjižnici, dok neki knjige kupuju ili čitaju online. Dakle, iz rezultata se može uočiti da članstvo pojedinih ispitanika nije povezano s uslugama knjižnice, odnosno da razlozi tome što nisu učlanjeni u knjižnicu nisu ti da se mladi ne osjećaju dobrodošlo u knjižnici ili da ne mogu pronaći knjige koje ih zanimaju. Ipak, u tom slučaju, trebalo bi poraditi na tome da se organiziraju zanimljivi događaji i aktivnosti koji će one mlade koji ne čitaju u slobodno vrijeme potaknuti na čitanje ili bar dolazak u knjižnicu radi sudjelovanja u nekom programu. Uz to, potrebno je poraditi i na tome da se knjižnica približi mladima kojima je predaleko, na primjer bibliobusom ili stacionarima. Nadalje, rezultati su pokazali da većina učenika ne sudjeluje u aktivnostima koje knjižnica organizira te da nemaju prijedlog za neku aktivnost koju bi željeli da se provodi u gradskoj knjižnici, dok bi ih na sudjelovanje u aktivnostima povezanima $\mathrm{s}$ čitanjem iz užitka najprije potaknulo sudjelovanje prijatelja u istom programu te zanimljivost programa. Ovi rezultati podudaraju se s nekim ranije provedenim istraživanjima (Howard; Bishop i Bauer). Moguće je da mladi ne sudjeluju u aktivnostima i programima koje knjižnica nudi zbog toga što s njima nisu upoznati ili misle da takve aktivnosti ne posjećuju njihovi vršnjaci, ali i zbog toga što se u slobodno vrijeme bave nekim drugim aktivnostima. Stoga bi se trebalo poraditi na organiziranju programa koji će odgovarati interesima mladih, mlade uključiti u planiranje, osmišljavanje, organizaciju i provedbu tih programa te programe promovirati na društvenim mrežama, na mjestima u gradu koje mladi često posjećuju i u školama.

Kada su upitani dobivaju li poticaje za čitanje iz užitka u samoj Gradskoj knjižnici i čitaonici Đakovo, ispitanici u ovom istraživanju naveli su da ih GKČ Đakovo svojim aktivnostima niti potiče niti ne potiče na čitanje iz užitka, dok je manje onih koji su izjavili da ih ili potiče ili ne potiče. Također, većina ispitanika ne zna potiče li gradska knjižnica učenike dovoljno na čitanje iz užitka. Unatoč tome, nisu imali rješenja ili prijedlog što bi gradska knjižnica mogla učiniti i kako bi ih više mogla potaknuti na čitanje. Razlog tome mogao bi biti u tome što mladi nisu dovoljno upoznati s uslugama i programima knjižnice i što u njima većinom ne sudjeluju, što ponovo upućuje na to da bi se aktivnosti koje knjižnica provodi trebale bolje i više promovirati. Kada bi mladi posjećivali programe koje knjižnica organizira, možda bi više osjećali da ih knjižnica potiče na čitanje i podržava njihove različite interese. 


\section{Zaključak}

Razvijanje vještine čitanja i čitateljskih navika, potrebe i interesa osigurava održavanje pozitivnog stava prema čitanju tijekom života. Razdoblje u kojem se ti interesi i potrebe često mijenjaju je adolescencija i mladi često, zbog promjena koje im se događaju, počinju zanemarivati čitanje i baviti se drugim aktivnostima. Uzrok prestanka čitanja kod mladih često je u tome što ne mogu pronaći knjige s njima zanimljivim temama. Stoga je vrlo važno da narodne knjižnice promoviraju svoje usluge, one informativne koje će mlade uputiti na to da u knjižnici mogu pronaći knjige vrlo širokog raspona tema, ali i one društvene koje će ih uputiti na to da u knjižnicu mogu doći i zbog raznih organiziranih aktivnosti i druženja. Knjižnice trebaju odgovarati na potrebe mladih kako bi ih potaknule na čitanje, ali i zadržale kao trenutne i trajne korisnike. Da bi u tome uspjele, trebaju provoditi ankete o programima i uslugama koje pružaju mladima kako bi dobili točne i relevantne informacije o onome što rade dobro, a što bi mogli raditi bolje. Prema rezultatima istraživanja prikazanog u radu, može se zaključiti da je u GKČ Đakovo potrebno poraditi na aktivnostima koje će mladima biti dovoljno zanimljive da im nazoče te ih tako potiču na čitanje. Budući da je istraživanje uključivalo samo učenike Gimnazije A. G. Matoša u Đakovu, rezultati pokazuju mišljenje samo tih učenika, pa bi se ovo istraživanje moglo proširiti i na ostale srednje škole u Đakovu da bi se dobila potpuna slika čitateljskih potreba i interesa mladih u Đakovu, što bi svakako dalo cjelovitiju sliku kakvo mišljenje i dojam mladi imaju o Gradskoj knjižnici, pa bi to istraživanje, kao i ovo, moglo biti polazište za unaprjeđenje postojećih usluga i programa za poticanje mladih na čitanje i ispunjavanje njihovih potreba i interesa. Promatrajući i prateći aktivnost GKČ Đakovo nakon, ali i prije provođenja ovog istraživanja, može se konstatirati da se knjižnica nastoji približiti mladim korisnicima i da upravo s tim ciljem često organizira razne aktivnosti za mlade. Budući da veliki broj mladih uključenih u ovo istraživanje najčešće ne posjećuje i/ili ne zna da te aktivnosti postoje i da se provode, širenje informacija i promoviranje knjižničnih programa za mlade nameće se kao logično i ujedno jednostavno početno rješenje najprije da bi se doprlo do većeg broja mladih koji će doći u knjižnicu, čime se otvaraju vrata za širenje nebrojenih potencijala i mogućnosti poticanja čitanja u knjižnici.

\section{LITERATURA}

Agosto, D. Why do teens use libraries?: Results of a public library use survey. // Public Libraries 46, 3(2007), 55-62. [citirano: 2020-10-26]. Dostupno na: https://www. researchgate.net/publication/292710242_Why_do_teens_use_libraries_Results_ of_a_public_library_use_survey/link/5718bd0808ae 30c3f9f1896b/download. 
Agosto, D.; S. Hughes-Hasell. People, places, and questions: An Investigation of the everyday life information-seeking behaviors of urban young adults. // Library \& Information Science Research 27, 2(2005), 141-163. [citirano: 2020-10-26]. Dostupno na: https://www.sciencedirect.com/science/article/abs/pii/S0740818805000046.

Anish, C.A.; J. Jincy,. Reading habits of higher secondary school students: A Study. // Imperial Journal of Interdisciplinary Research 3, 5(2007). [citirano: 2020-06-02]. Dostupno na: http://www.onlinejournal.in/IJIRV3I5/342.pdf.

Asemi, A. A survey on the teenagers' need of public libraries' resources and services (LRs \& LSs). // Journal of libray \& information technology 38, 4 (2018), 295-301. [citirano: 2020-10-26]. Dostupno na: https://pdfs.semanticscholar.org/d234/8b46c265f32da511c2a0db426e5516943968.pdf.

Bishop, K; P. Bauer. Attracting young adults to public libraries: Frances Henne/YALSA/ VOYA research grant results. // Journal of youth services in libraries 15, 2 (2002), 36-44.

Clark, K.; A. Foster. Children's and young people's reading habits and preferences: The Who, what, why, where and when. // Nationa Literacy Trust (2005), 2-94. [citirano: 2020-08-17]. Dostupno na: https://files.eric.ed.gov/fulltext/ED541603.pdf.

Cook, S. J.; R. S. Parker; C. E. Pettijohn. Young teens and the public library: An American investigation. [citirano: 2020-10-26]. Dostupno na: https://bbf.enssib.fr/consulter/bbf-2008-06-0081-003.

Corradini, E. Teenagers analyse their public library. // New library world 107, 11/12 (2006), 481-498.

Corradini, E. Teens and library services: Experiences, expectations, perspectives: An Exploratory study: Dissertation proposal. University of Northumbria at Newcastle: University of Parma, 2004. Str. 2-19. Dostupno na: https://www.researchgate.net/ publication/33436328_Teens_and_library_services_experiences_expectations_perspectives_an_exploratory_study_dissertation_proposal.

Fisher, H. A teenage view of the public library: What are the students saying? // APLIS 16, 1 (2003), 4-16. [citirano: 2020-10-26]. Dostupno na: https://search.informit. org/doi/abs/10.3316/ielapa.971882240794092

Gorman, M.; T. Suellentrio. The philosophy of service to young adults. New York: Neal-Schuman Publishers, 2009.

Hopper, R. What are teenagers reading?: Adolescent fiction reading habits and reading choices. // Literacy 39,3 (2005), 113-120. [citirano: 2020-08-17]. Dostupno na: https://onlinelibrary.wiley.com/doi/epdf/10.1111/j.1467-9345.2005.00409.x.

Howard, V. The importance of pleasure reading in the lives of young teens: Self-identification, self-construction and self-awareness. // Journal of Librarianship and Information Science 43, 1(2011), 46-55. [citirano: 2021-06-02]. Dostupno na: https://journals.sagepub.com/doi/10.1177/0961000610390992. 
Howard, V. What do young teens think about the public library? // The library quaterly 81, 3(2011), 321-344. [citirano: 2020-10-26]. Dostupno na: https://www.jstor.org/stable/10.1086/660134?origin=JSTOR-pdf.

IFLA-ine smjernice za narodne knjižnice. // Vjesnik bibliotekara Hrvatske 55, 1 (2012), 124-132.

Ilišin, V.; Radin, F. Interesi i slobodno vrijeme mladih. // Mladi uoči trećeg milenija. / urednici V. Ilišin i F. Radin. Zagreb: Institut za društvena istraživanja u Zagrebu; Državni zavod za zaštitu obitelji, materinstva i mladeži, 2002. Str. 269-303. [citirano: 2021-10-07]. Dostupno na: http://knjiznica.idi.hr/epb/Mutm.pdf.

Ilišin, V. Neke dimenzije slobodnog vremena mladih. // Generacija osujećenih: Mladi u Hrvatskoj na početku 21. stoljeća. / urednice V. Ilišin i V. Spajić Vrkaš. Zagreb: Institut za društvena istraživanja u Zagrebu, 2017. Str. 293-316.

IFLA Professional Report: Guidelines for library services for young adults [citirano: 2020-06-02]. Dostupno na: https://www.ifla.org/files/assets/libraries-for-children-and-ya/publications/ya-guidelines2-en.pdf.

Kunz, J. C. Understanding your reader's needs and wants can lead to higher book sales, 2019. [citirano: 2020-07-07]. Dostupno na: https://kunzonpublishing.com/2019/03/ understanding-your-readers-needs-and-wants-can-lead-to-higher-book-sales/.

Kushmeeta Chettri, M.; , S. K. Rout. Reading habits: An Overview. // IOSR Journal of Humanities and Social Science 14, 6(2013), 13-17. [citirano: 2021-06-02]. Dostupno na: http://www.iosrjournals.org/iosr-jhss/papers/Vol14-issue6/C01461317. pdf?id $=6700$.

Maharasi, I.; S. Maulani. High school students' reading habit and perception on reading for pleasure. // International Journal of Indonesian Education and Teaching 3, 1(2019), 80-89. [citirano: 2021-06-02]. Dostupno na:

https://www.researchgate.net/publication/335012807_HIGH_SCHOOL_STUDENTS'_READING_HABIT_AND_PERCEPTION_ON_READING_FOR_PLEASURE.

Mahood, K. A passion for print: Promoting reading and books to teens. Westport: Libraries Unlimited, 2006.

Moeller, R. A.; K. E. Becnel. You are what you read: Young adult literacy and identity in rural America. // YRLA 6(2015), 1-24. [citirano: 2021-06-12]. Dostupno na: http://www.yalsa.ala.org/jrlya/wp-content/uploads/2015/04/You-Are-What-YouRead_Final.pdf.

Sabolović-Krajina, D. Čitanje: Sposobnost važnija nego ikada. // Riječi teške od života: Suvremene težnje u nastavi hrvatskoga jezika: Stazama Lovrakovih sljedbenika: Zbornik. / glavni urednik V. Strugar. Bjelovar: Ogranak Hrvatskog pedagoškog-književnog zbora Bjelovarsko-bilogorske županije, 2003. Str. 35-42.

Sabolović-Krajina, D. Čitateljske navike tinejdžera u Hrvatskoj. [citirano: 2021-0602]. Dostupno na: http://dzs.ffzg.unizg.hr/text/sabolovic-krajina_1993.htm. 
Sheldrick Ross, C. Reading interests. // Encyclopedia of Library and Information Sciences. 3rd ed. Taylor \& Francis, 2010. Str. 1-10. [citirano: 2021-06-09]. Dostupno na: https://www.researchgate.net/publication/258764077_Reading_Interests.

Snowball, C. Enticing teenagers into the library. // Library Review 57, 1(2008), 25-35. [citirano: 2020-10-26]. Dostupno na:

https://espace.curtin.edu.au/bitstream/handle/20.500.11937/6057/20507_downloaded_stream_495.pdf? sequence $=2 \&$ isAllowed $=y$.

Snowball, C. Teenagers talking about reading and libraries. // Australian Academic \& Research Libraries 39, 2 (2008), 106-120. [citirano: 2020-10-26]. Dostupno na: https://www.tandfonline.com/doi/abs/10.1080/00048623.2008.10721336.

Stričević, I.; S. Jelušić, S. Knjižnične usluge za mlade: Modeli i koncepti. // Vjesnik bibliotekara Hrvatske, 53, 1(2010), 1-34.

Walter, V. A. Public library service to children and teens: A Research agenda. // Library trends 51, 4 (2003), 571-589. [citirano: 2020-10-26]. Dostupno na:

https://www.ideals.illinois.edu/bitstream/handle/2142/8488/librar?sequence=1. 